\title{
Molecular Identification of Yeasts Isolated from Dadih by RFLP-PCR and Assessment on Their Ability in Utilizing Lactate
}

\author{
YOGA DWI JATMIKO $^{1}$, MIGUEL DE BARROS LOPES ${ }^{2}$, AND MARY D BARTON $^{2}$ \\ 'Department of Biology, Faculty of Sciences, Universitas Brawijaya, \\ Jalan Veteran, Malang, East Java 65145, Indonesia; \\ ${ }^{2}$ School of Pharmacy and Medical Sciences, University of South Australia, \\ City East Campus, Adelaide, South Australia 5000, Australia
}

\begin{abstract}
A wide variety of yeasts have been involved in traditional fermented foods, and potentially contributed to the development of product properties. The existence of indigenous yeasts in dadih, a traditionally fermented form of buffalo milk of West Sumatera, has been reported but an accurate identification is still required to be conducted. This study was aimed to identify yeasts isolated from dadih using a molecular approach, and to evaluate their lactate utilization. A total of 51 isolates were characterized and identified as Pichia jadinii and Candida stellimalicola using PCR amplification of the 5.8S - internal transcribed spacer region combined with restriction fragment length polymorphism (RFLP) analyses and gene sequencing. The former species were the dominant one in this tested product. Their ability to utilize lactate was demonstrated, indicating that they could modify the sensory characteristics of dadih, and hence interact with the indigenous lactic acid bacteria in dadih. The restriction profiles of the dadih yeasts can be used as a data base for rapid identification of yeasts in the future. Further work is still needed to elucidate the dadih yeast ecology.
\end{abstract}

Key words: dadih, internal transcribed spacer (ITS), lactate, PCR, yeasts

Beragam jenis khamir telah terlibat dalam produk fermentasi pangan tradisional, dan khamir tersebut mampu mempengaruhi karakteristik dari produk tersebut. Keberadaan khamir indigenus di dalam dadih, yaitu produk susu kerbau yang difermentasi secara tradisional dari Sumatra Barat, telah dilaporkan. Tetapi identifikasi secara akurat masih diperlukan. Penelitian ini bertujuan untuk mengidentifikasi khamir yang diisolasi dari dadih secara molekuler, dan mengevaluasi kemampuan khamir tersebut dalam menggunakan laktat. Sejumlah 51 isolat khamir telah dikarakterisasi dan diidentifikasi sebagai Pichia jadinii dan Candida stellimalicola menggunakan amplifikasi PCR daerah 5.8S-ITS dan dilanjutkan dengan analisis restriction fragment length polymorphism (RFLP) dan pembacaan deret DNA dari gen. P. jadinii merupakan salah satu spesies khamir yang mendominasi pada produk dadih yang diamati. Kedua jenis khamir tersebut juga mampu memanfaatkan laktat. Hal ini menunjukkan bahwa khamir tersebut dapat memengaruhi karakteristik sensori dari dadih. Selain itu, khamir dinilai mampu berinteraksi dengan bakteri asam laktat indigenus dalam dadih. Pola restriksi hasil analisis RFLP dari khamir tersebut dapat digunakan sebagai basis data untuk identifikasi khamir di penelitian mendatang. Penelitian lebih lanjut masih diperlukan untuk mempelajari ekologi khamir di dalam produk dadih.

Kata kunci : dadih, internal transcribed spacer (ITS), khamir, laktat, PCR

The existence of yeasts in a range of spontaneously fermented milk products has been investigated by several researchers (Gadaga et al. 2000; Abdelgadir et al. 2001; Lore et al. 2005; Kebede et al. 2007; Zhang et al. 2008; Rahman et al. 2009). As well as being potential spoilage microorganisms, the presence of indigenous yeasts in naturally fermented milk (NFM) products may contribute to the development of characteristic of texture and flavor (Narvhus and Gadaga 2003).

The presence of indigenous yeasts in dadih has been noted but not well studied (Hosono et al. 1989). Yeasts were found in dadih as reported by some researchers which were Endomyces lactis (Hosono et al. 1989), Candida tropicalis, Geotrichum candidum

*Corresponding author, Phone: +62-341-575840, Fax : +62-341-575841. E-mail : jatmiko_yd@ub.ac.id.
(Gandjar 1983; Roositta et al. 2003), Candida parapsilosis (Gandjar 1983), and Saccharomyces cerevisiae (Roositta et al. 2003).

Yeasts in dadih generally have been identified traditionally based on phenotypic characteristics. This method is considered to be time consuming and fairly inaccurate (Esteve-Zarzoso et al. 1999; Senses-Ergul et al. 2006). Molecular approach with reference to 5.8SITS region has been successfully applied to identify yeast species from a range of fermented food products (Abdelgadir et al. 2001; Jeyaram et al. 2008; Rahman et al. 2009). In this study, PCR amplification of the 5.8S-ITS region followed by restriction fragment length polymorphism (RFLP) has been used to identify the yeast species present in dadih. To study the potential effect of these yeast on dadih, such as ability to utilize lactic acid -the major metabolite of lactic acid bacteria (LAB)- was evaluated. 


\section{MATERIALS AND METHODS}

Isolates. Fifty one of yeasts isolated from dadih by using de Man Rogosa Sharpe (MRS) agar medium which were derived from previous research (Jatmiko et al. 2010) were included in the study. A phenotypic characterization (shape of the cell and colony appearance) was carried out among these yeast isolates.

Media. Yeast peptone dextrose (YPD) agar and broth supplemented with $2 \%(\mathrm{w} / \mathrm{w})$ of D-glucose were used for cultivation of yeast isolates. Minimal media containing yeast nitrogen base without amino acids (Difco, BD Diagnostics, USA) and 2\% (v/v) of lactic acid (Sigma-Aldrich) was used for evaluation of utilization of lactate by yeasts.

Colony-PCR Amplification. The oligonucleotide primers used in this experiment were ITS 1 (5'-TCCGT AGGTGAACCTGCGG-3') and ITS 4 (5'-TCCTCCG CTTATTGATATGC-3'). Colony-PCR was performed in this study where a small amount of yeast colony used directly as DNA templates for the PCR amplification. A small amount of a single colony was taken from the solid media, and placed at the bottom of sterile PCR tubes using a sterile loop. Subsequently, the colony in the PCR tubes was heated at $100{ }^{\circ} \mathrm{C}$ in a Microwave oven (Panasonic) for one minute. After this, the master mix reagents were dispensed into the tubes. The DNA amplification of the 5.8S-ITS region was carried out in a Mycycler thermal cycle (Bio-Rad Laboratories, Hercules, CA, USA) with following components: $5 \mu \mathrm{L}$ of $5 x$ PCR buffer, $1.25 \mu \mathrm{L}$ of $50 \mathrm{mM} \mathrm{MgCl}_{2}, 2.5 \mu \mathrm{L}$ of $2.5 \mathrm{mM}$ dNTPs ( $2 \mathrm{mM}$ each dATP, dCTP, dGTP and dTTP), $0.25 \mu \mathrm{L}$ of Taq polymerase $\left(5 \mathrm{U}_{\mu} \mathrm{L}^{-1}\right)$ and $1.5 \mu \mathrm{L}$ of $5 \mu \mathrm{M}$ each primer. To obtain a final volume of $25 \mu \mathrm{L}$, a quantity of sterile milli Q water was added. The PCR reaction was run with an initial denaturation at $94^{\circ} \mathrm{C}$ for $5 \mathrm{~min}$, followed by 35 cycles of $94^{\circ} \mathrm{C}$ for $1 \mathrm{~min}, 56^{\circ} \mathrm{C}$ for $1 \mathrm{~min}$ and $72^{\circ} \mathrm{C}$ for $1 \mathrm{~min}$, with a final extension at $72^{\circ} \mathrm{C}$ for $5 \mathrm{~min}$ and a terminal hold at $4{ }^{\circ} \mathrm{C}$. Amplified products were separated by electrophoresis in a $1.5 \%$ agarose gel and stained with ethidium bromide $\left(0.5 \mu \mathrm{g} \mathrm{mL}^{-1}\right)$.

RFLP Analysis. After obtaining a good yield of product following electrophoresis, RFLP analysis was performed for differentiation of 51 yeast isolates. A total volume of $10 \mu \mathrm{L}$ was used for RFLP analysis which comprised $9 \mu \mathrm{L}$ of amplicons, $1 \mu \mathrm{L}$ of buffer (composition dependent on the enzymes), and $0.2 \mu \mathrm{L}$ of restriction enzymes (HaeIII, HinfI, and EcoRI). The solution was incubated at the optimum temperature for the enzyme activity for at least 3 hours. Following this incubation, $5 \mu \mathrm{L}$ of the RFLP product plus $2 \mu \mathrm{L}$ of loading dye were dispensed into the wells of the agarose gel and then electrophoresed as mentioned in the previous section. Since species identification of yeast can be determined by comparing the result of RFLP patterns with the existing databases, sequencing of the ITS region product was also performed when restriction profiles of the reference strains are not yet available.

Purification of DNA Products. PCR products were purified for sequencing by using UltraClean PCR clean-up kit (Mo Bio Laboratories Inc, Solena Beach, CA, USA.) according to the manufacturer's instructions.

DNA Sequencing Analysis. Sequencing of the DNA products was performed using Big Dye Terminator v3.1 cycle sequencing ready reactions (Applied Biosystem, Foster City, CA, USA) at the DNA Sequencing Facility, Flinders Medical Centre, Adelaide. The nucleotide sequences were analysed by using BioEdit software (version 7.0.9.0). Homology searches were performed using Basic Local Alignment Search Tool (BLAST) at the National Centre of Biotechnology Information website (http://www.ncbi. nlm.nih.gov/BLAST/).

Evaluation of Lactate-Utilizing Yeasts. A number of yeast isolates were selected to represent the different strains obtained from the dadih samples. Each selected isolate was revived from frozen stocks and subcultured twice in YPD broth at $37{ }^{\circ} \mathrm{C}$ in $5 \% \mathrm{CO}_{2}$. Following this incubation, $1 \%\left(\mathrm{v} \mathrm{v}^{-1}\right)$ of cultures was inoculated into minimal medium containing $2 \%\left(\mathrm{v} \mathrm{v}^{-1}\right)$ of lactic acid, and then incubated at $37{ }^{\circ} \mathrm{C}$ in $5 \% \mathrm{CO}_{2}$ for $48 \mathrm{~h}$. The incubation condition was carried out without shaking in order to imitate the dadih fermentation condition. The cell count and $\mathrm{pH}$ were measured before and after incubation in duplicate. A spread plate method was used to determine the total yeast counts. The utilization of lactic acid was shown by subtracting between initial and final concentration of D/L-lactate measured using K-DLATE kit (Megazyme, Ireland). The reagent preparation and calculation of the lactate were performed according to the manufacturer's instructions. Minimal medium without cultures was used as a control. The isolates were also grown in the minimal medium without lactic acid.

\section{RESULTS}

Molecular Characterization and Identification of Dadih Yeasts. A total of 51 yeast isolates were characterized and identified using PCR amplification 
Table 1 Characterization and identification of dadih yeasts

\begin{tabular}{|c|c|c|c|c|c|c|c|c|}
\hline \multirow[t]{2}{*}{ Group } & \multirow{2}{*}{$\begin{array}{c}\text { Cell- } \\
\text { morphology }\end{array}$} & \multirow{2}{*}{$\begin{array}{l}\text { Number of } \\
\text { isolates }\end{array}$} & \multirow{2}{*}{$\begin{array}{c}\text { ITS-PCR } \\
(\mathrm{bp})\end{array}$} & \multicolumn{3}{|c|}{ RFLP (bp) } & \multirow{2}{*}{$\begin{array}{c}\text { BLAS T } \\
\text { analysis ( } \%)\end{array}$} & \multirow[t]{2}{*}{ Identific ation } \\
\hline & & & & Hae III & HinfI & EcoR I & & \\
\hline I & Small ovoid & 8 & 575 & $\begin{array}{c}390 \\
145\end{array}$ & $\begin{array}{l}300 \\
275\end{array}$ & 575 & 98 & $\begin{array}{l}\text { Candida } \\
\text { stellimalicola }\end{array}$ \\
\hline II & Large ovoid & 43 & 520 & 520 & $\begin{array}{l}300 \\
220\end{array}$ & 520 & 99 & Pichiajadinii \\
\hline
\end{tabular}

of the 5.8S-ITS region combined with RFLP and gene sequencing. The restriction analysis results were in consistent with cell and colony appearance, which differentiated the yeast isolates into two groups (Table 1 and Fig 1). The restriction enzymes of HaeIII and HinfI successfully digested the amplicons and confirmed the presence of two different groups (species) indicates that the use of HaeIII and HinfI to digest the ITS-PCR products could provide a reproducible result. Based on DNA sequencing, the two species were identified as Pichia jadinii and Candida stellimalicola, with the GenBank accession number JQ 927546 and JQ 927545 respectively. The restriction profile of $P$. jadinii was also in agreement with the study conducted by Villa-Carvajal et al. (2006). Interestingly, $P$. jadinii (20 isolates) was only found in dadih from Gadut (District of Agam). In dadih collected from Sianok (District of Agam), C. stellimalicola was the only identified yeast species in the two days fermentation while the three days fermentation yielded seven isolates of $C$. stellimalicola. At the same time, $P$. jadinii was dominant in both two and three days fermentation (six and 17 isolates, respectively).

Utilization of Lactic Acid by Yeasts. During incubation in lactate medium, total lactate declined slightly in the presence of both yeasts (P. jadinii and $C$. stellimalicola). This was correlated with the increase in the $\mathrm{pH}$ values of the medium. All of the tested yeast strains were more active in utilizing D-lactate rather than L-lactate. Interestingly, co-cultivation of the two yeasts did not increase use of lactate significantly (Fig 2).

\section{DISCUSSION}

To our knowledge, this is the first report on the isolation of these two yeast species from dadih which means that the role of yeast in determining the flavor characteristics and sensory properties of dadih may have been overlooked. The morphological study of $P$. jadinii showed that the cell characters (shape of the cell) were in consistent with the literature, in that they were ovoid in shaped and large in size (3.5-4.5) x (7-13)

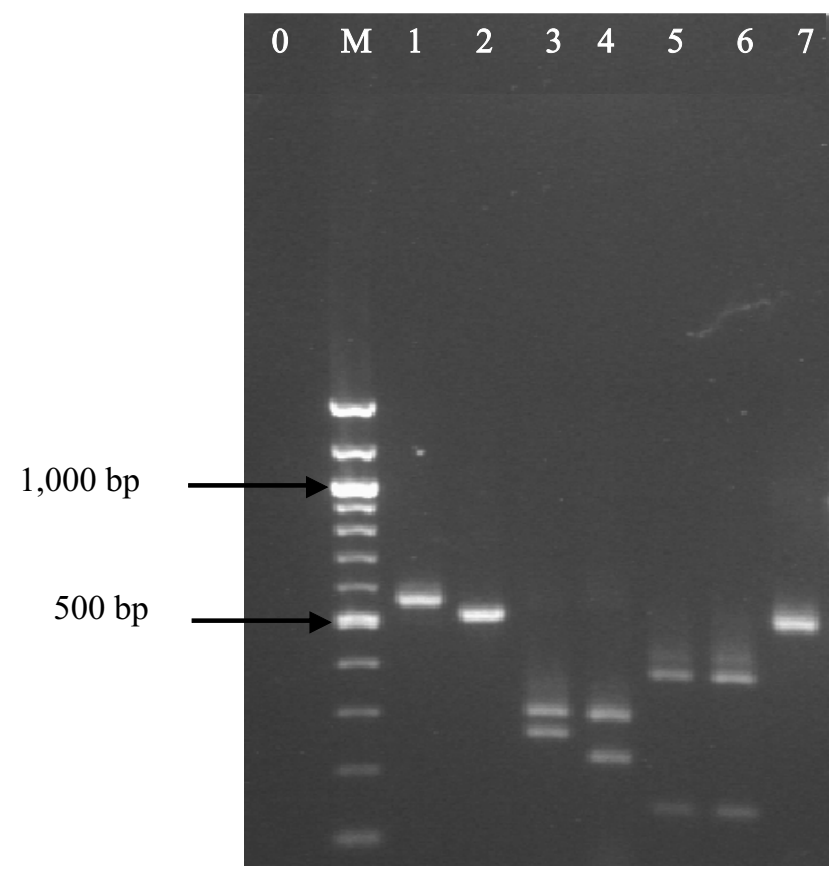

Fig 1 Internal Transcribed Spacer -PCR products and their restriction analysis with the endonuclease HinfI and HaeIII Lane M: 100 bp DNA marker; lane 0: sterile milliQ $\mathrm{H}_{2} \mathrm{O}$; lane 1: group II (isolate $\mathrm{S} 1.04$ ), lane 2: group I (isolate S2.31), lane 3: group II (isolate G.20), lane 4: group I (isolate S2.29), lane 5-6: group II (isolate G.19 and S2.03), lane 7: group I (isolate S2.33) (HinfI: lane 3-4; HaeIII: lane 5-7).

$\mu \mathrm{m}$ (Lodder 1970) . C. stellimalicola was first isolated from star apple (Ma-Fueng) in Thailand (Suzuki et al. 1994). In contrast with $P$. jadinii, the cellular morphology of $C$. stellimalicola is relatively smaller than that of P.jadinii. The cells are (1.8-4.0) x (1.8-4.2) $\mu \mathrm{m}$, and ovoid in shape (Suzuki et al. 1994). P. jadinii (anamorph of $C$. utilis) and $C$. stellimalicola was grouped in a similar group on the basis of $18 \mathrm{~S}$ rRNA gene sequence divergence (Suzuki and Nakase 2002). Hence, based on the phylogenetic studies these yeast species are closely related.

The presence of the two species of yeasts in dadih indicates that these species could reduce acidic properties of dadih. Although unable to utilize lactose, these species' ability to use lactate may explain their presence in dadih (Fig 2) (Lodder 1970; Suzuki et al. 1994). It should be noted that in our study the cultures 


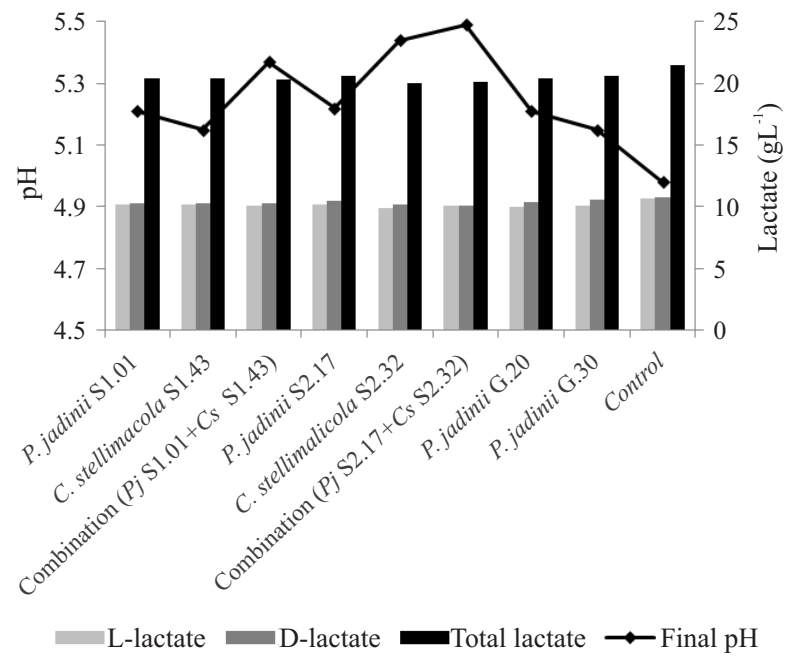

Fig 2 The utilization of D / L-lactate and total lactate by dadih yeasts incubated at $37{ }^{\circ} \mathrm{C}$ for $48 \mathrm{~h}$. Control: without cultures; P: Pichia; C: Candida.

were incubated without shaking; as the two are obligate aerobes, it is predicted that if oxygenation was increased, growth and utilization of $\mathrm{D} / \mathrm{L}$ lactate would be improved. Lactic acid produced by LAB can be assimilated further only by aerobic metabolic pathway (Lowes et al. 2000). This experiment was designed to imitate dadih condition, which was semi-aerobic condition; as a result the lactate utilization in the medium was not increased significantly. Their role in dadih requires further study. It is expected that these yeasts could live in the semi-aerobic condition as in the dadih fermentation process and may have adapted to the dadih environment by assimilating the lactic acid. The source of these yeasts also remains unknown and a further ecological study to assess microbiological condition of bamboo containers and the banana leaf covers, as well as the buffalo milk are interesting to study .

To conclude, P. jadinii and C. stellimalicola were detected as non-LAB cultures of tested dadih. Their ability to utilize lactic acid was demonstrated, indicating that they could modify the sensory characteristics of dadih. A more detailed analysis using an appropriate yeast medium in place of MRS would be useful to further establish the dadih yeast ecology. In addition, the restriction profiles of the dadih yeasts can be used as a data base of the rapid identification of yeasts.

\section{ACKNOWLEDGEMENT}

This work was supported by Australian Development Scholarships 2008-2010 from The Australian
Agency for International Development (AusAID). The authors wish to thank Ingrid Surono for the assistance during dadih sample collection.

\section{REFERENCES}

Abdelgadir WS, Hamad SH, Moller PL, Jakobsen M. 2001. Characterisation of the dominant microbiota of Sudanese fermented milk Rob. Int Dairy J. 11(1-2): 6370. doi: 10.1016/S0958-6946(01)00042-5.

Esteve-Zarzoso B, Belloch C, Uruburu F, Querol A. 1999. Identification of yeasts by RFLP analysis of the $5.8 \mathrm{~S}$ rRNA gene and the two ribosomal internal transcribed spacers. Int J System Bacteriol. 49 (1): 329-337. doi: 10.1099/00207713-49-1-329.

Gadaga TH, Mutukumira AN, Narvhus JA. 2000. Enumeration and identification of yeasts isolated from Zimbabwean traditional fermented milk. Int Dairy J. 10(7): 459-466. doi: 10.1016/S0958-6946(00)00070-4.

Gandjar I. 1983. Utilization of microorganisms for the production of foods, with special reference to Indonesia. Presented in Workshop on Single-Cell Protein (Summary Report). February 1st-5th, 1983. Jakarta. Indonesia.

Hosono A, Wardojo R, Otani H. 1989. Microbial flora in 'Dadih', a traditional fermented milk in Indonesia. Lebensm. Wiss. U. Technol. 22: 20-24.

Jatmiko YD, De Barros Lopes M, Barton MD. 2010. Isolation and antimicrobial potency of indigenous lactic acid bacteria isolated from dadih, a traditional fermented buffalo milk from Indonesia [thesis]. Adelaide (AU): University of South Australia.

Jeyaram K, Singh WM, Capece A, Romano P. 2008. Molecular identification of yeast species associated with 'Hamei' — A traditional starter used for rice wine production in Manipur, India. Int J Food Microbiol. 124(2): 115-125. doi: 10.1016/j.ijfoodmicro.2008. 02.029 .

Kebede A, Viljoen BC, Gadaga TH, Narvhus JA, LourensHattingh A. 2007. The effect of container type on the growth of yeast and lactic acid bacteria during production of Sethemi, South African spontaneously fermented milk. Food Res Int. 40 (1): 33-38. doi: 10.1016/j.foodres.2006.07.012.

Lodder J. 1970. Yeast: a taxonomy study, 2nd revised ed, North-Holland Publishing Company, AmsterdamLondon.

Lore TA, Mbugua SK, Wangoh J. 2005. Enumeration and identification of microflora in suusac, a Kenyan traditional fermented camel milk product. LWT-Food Sci Tech. 38(2):125-130. doi: 10.1016/j.lwt.2004. 05.008 .

Lowes KF, Shearman CA, Payne J, MacKenzie D, Archer DB, Merry RJ, Gasson MJ. 2000. Prevention of yeast 
spoilage in feed and food by the yeast mycocin HMK. Appl Environ Microbiol. 66(3): 1066-1076. doi: 10.1128/AEM.66.3.1066-1076.2000.

Narvhus JA, Gadaga TH. 2003. The role of interaction between yeasts and lactic acid bacteria in African fermented milks: a review. Int J Food Microbiol. 86(12): 51-60. doi: 10.1016/S0168-1605(03)00247-2.

Rahman N, Xiaohong C, Meiqin F, Mingsheng D. 2009. Characterization of the dominant microflora in naturally fermented camel milk shubat. World J Microbiol Biotechnol. 25(11): 1941-1946. doi: 10. 1007/s11274-009-0092-5.

Roositta LB, Chairunissa H, Kusmayadi S. 2003. Studi tentang isolasi dan identifikasi spesies yeast dalam produk dadih susu kerbau berasal dari Sumatera Barat [Study on isolation and identification of yeast species in buffalo milk of dadih from West Sumatera]. Pertemuan Ilmiah Tahunan Perhimpunan Mikrobiologi Indonesia. August 29th-30th, 2003. Bandung. Indonesia.

Senses-Ergul S, Agoston R, Belak A, Deak T. 2006. Characterization of some yeasts isolated from foods by traditional and molecular tests. Int J Food Microbiol. 108(1): 120-124. doi: 10.1016/j.ijfoodmicro.2005. 10.014 .

Suzuki M, Nakase T. 2002. A phylogenetic study of ubiquinone-7 species of the genus Candida based on $18 \mathrm{~S}$ ribosomal DNA sequence divergence. J Gen Appl Microbiol. 48(1):55-65. doi: 10.2323/jgam.48.55.

Suzuki M, Nakase T, Komagata K. 1994. Candida stellimalicola, a new species of anamorphic yeast isolated from star apple in Thailand. J Gen Appl Microbiol. 40(2): 115-121. doi: 10.2323/jgam.40.115.

Villa-Carvajal M, Querol A, Belloch C. 2006. Identification of species in the genus Pichia by restriction of the internal transcribed spacers (ITS1 and ITS2) and the 5.8S ribosomal DNA gene. Anton Leeuw. 90(2): 171181. doi: 10.1007/s10482-006-9071-0.

Zhang H, Xu J, Wang J, Menghebilige, Sun T, Li H, Guo M. 2008. A survey on chemical and microbiological composition of kurut, naturally fermented yak milk from Qinghai in China. Food Control. 19(6): 578-586. doi: 10.1016/j.foodcont.2007.06.010. 